\title{
Short-term storage in vitro and large-scale propagation of grapevine genotypes
}

\author{
Rafael de Carvalho Silva( ${ }^{(1)}$, Zanderluce Gomes Luis ${ }^{(2)}$ and Jonny Everson Scherwinski-Pereira ${ }^{(3)}$
}

\begin{abstract}
(1)Universidade Federal do Amazonas, Avenida General Rodrigo Octávio Jordão Ramos, № 3.000, Bairro Coroado I, CEP $69057-070$ Manaus, AM, Brazil. E-mail: carvalho_fael@yahoo.com.br (2)Universidade de Brasília, Instituto de Biologia, Campus Universitário Darcy Ribeiro, CEP 70910-900 Brasília, DF, Brazil. E-mail: zanbio@hotmail.com ${ }^{(3)}$ Embrapa Recursos Genéticos e Biotecnologia, Avenida W5 Norte (Final), CEP 70770-917 Brasília, DF, Brazil. E-mail: jonny@cenargen.embrapa.br
\end{abstract}

\begin{abstract}
The objective of this work was to evaluate the large-scale propagation of grapevine genotypes after short-term storage in vitro. Microshoots from ten grapevine genotypes were used. The following storage temperatures were evaluated: 10,20 , and $25^{\circ} \mathrm{C}$. After short-term storage, the shoots were propagated in up to five successive subcultures, to assess the large-scale propagation of the germplasm maintained under conditions of minimal growth. The propagated shoots were rooted in different concentrations of indolbutiric acid (IBA) and acclimatized in greenhouse. The best temperature for short-term storage in vitro and survival of the genotypes was $20^{\circ} \mathrm{C}$. In the propagation phase, the highest number of shoots per explant was found in the subcultures 4 and 5, with averages of 4.9 and 4.8 shoots per explant, respectively. In the rooting phase, the best results for number of roots were obtained using a culture medium supplemented with $0.4 \mu \mathrm{mol} \mathrm{L}^{-1}$ of IBA, with an average of three roots per shoot. During the acclimation phase, a survival rate higher than $95 \%$ was achieved after 30 days in the greenhouse. Grapevine genotypes maintained for six months in vitro, at $20^{\circ} \mathrm{C}$, can be micropropagated in large scale.
\end{abstract}

Index terms: Vitis, germplasm, ex situ conservation, in vitro conservation, micropropagation, minimal growth.

\section{Conservação de curto prazo in vitro e propagação em larga escala de genótipos de videira}

Resumo - O objetivo deste trabalho foi avaliar a propagação em larga escala de genótipos de videira após curto período de conservação in vitro. Foram utilizados microbrotos de dez genótipos de videira. As seguintes temperaturas de conservação foram avaliadas: 10,20 e $25^{\circ} \mathrm{C}$. Após o curto período de conservação, as brotações foram multiplicadas, por até cinco subcultivos sucessivos, para avaliar o potencial propagativo em larga escala do germoplasma mantido sob condições de crescimento mínimo. As brotações regeneradas foram enraizadas em diferentes concentrações de ácido indolbutírico (AIB) e aclimatizadas em casa de vegetação. A melhor temperatura para a conservação de curto prazo in vitro e para a sobrevivência dos genótipos foi a de $20^{\circ} \mathrm{C}$. $\mathrm{Na}$ fase de multiplicação, o maior número de brotos foi verificado nos subcultivos 4 e 5 , com médias de 4,9 e 4,8 brotos por explante, respectivamente. Na etapa de enraizamento, os melhores resultados para número de raízes foram obtidos em meio de cultura suplementado com $0,4 \mu \mathrm{mol} \mathrm{L}-1$ de AIB, com média de três raízes por brotação. Durante a aclimatização, obteve-se índice de sobrevivência superior a 95\%, após 30 dias de permanência em casa de vegetação. Genótipos de videira em conservação por seis meses in vitro, a $20^{\circ} \mathrm{C}$, podem ser micropropagados em larga escala.

Termos para indexação: Vitis, germoplasma, conservação ex situ, conservação in vitro, micropropagação, crescimento mínimo.

\section{Introduction}

The family Vitaceae has about 900 species grouped into 14 genera, among which only Vitis produces edible fruit. Species of American (Vitis labrusca L.) and European (Vitis vinifera L.) origins stand out for their high economic value in two different markets: wine and table grape production. Europe is responsible for approximately $39 \%$ of the global production, followed by Asia (32\%), the Americas (20\%), Africa (6\%), and Oceania (3\%). In 2010, the Brazilian viticulture had a production area of 79,970 ha, yielding 1,305,670 tons of grapes (Food and Agriculture Organization of the United Nations, 2010).

Pesq. agropec. bras., Brasília, v.47, n.3, p.344-350, mar. 2012 
However, Brazilian and global production have encountered problems, mainly related to the occurrence of pests, which are causing a gradual decline in the productive vitality of the plants (Skiada et al., 2009). Consequently, some species are being included in germplasm banks to maintain the genetic diversity necessary for plant breeding programs (Schuck et al., 2011).

The genetic diversity of perennial plants, including grapevines, is usually sampled and maintained as live plants in field gene banks (Santana et al., 2008; Leão $\&$ Motoike, 2011). These collections are constantly in danger of being lost by exposure to environmental adversity, pest attacks, propagation issues, and frequent budget constraints, not to mention their potential to spread pests and diseases, which are important barriers to germplasm exchange (Engelmann, 2009).

Biotechnological strategies, based on concepts of in vitro plant cell, and tissue and organ culture have been developed as an alternative and an ancillary measure in response to the problems related to the conservation of plant germplasm in the field (Scherwinski-Pereira \& Costa, 2010; Vasanth \& Vivier, 2011). These techniques also have the potential to overcome some of the limitations inherent to conventional methods of conservation ex situ, and to facilitate the exchange of pest-free germplasm with other research institutions (Ray \& Bhattacharya, 2010).

In vitro culture under low, but above freezing temperatures (between 4 and $20^{\circ} \mathrm{C}$ ), has been effective for the conservation of various fruit species. In general, tropical fruit species are more sensitive to storage temperatures below $15^{\circ} \mathrm{C}$ than temperate-zone species. Temperate crops, such as raspberry, blackberry, apple, and pear, can be conserved at temperatures above $4^{\circ} \mathrm{C}$ with relative success (Scherwinski-Pereira \& Costa, 2010).

A crucial requirement for the success of in vitro conservation is the development of efficient protocols for micropropagation, since the existence of well-established propagation and regeneration protocols is decisive for the subsequent recovery, use, and exchange of conserved germplasm (Wang et al., 2004; Scherwinski-Pereira \& Costa, 2010). Some authors have reported the potential of the regeneration and plantlet production of grape (Biasi et al., 1998; Mhatre et al., 2000). However, studies on this potential following a period of in vitro maintenance are virtually non-existent in the literature.
The objective of this work was to evaluate the large-scale propagation of grapevine genotypes after short-term storage in vitro.

\section{Materials and Methods}

The experiments were carried out at the tissue culture and in vitro conservation laboratory of Embrapa Recursos Genéticos e Biotecnologia, Brasília, DF, Brazil, between 2007 and 2008. Approximately $1.0-\mathrm{cm}$ long microshoots, with one axillary bud and one lateral leaf, were taken from a total of ten grape genotypes: six $V$. vinifera genotypes ('Brasil', 'Flora', 'Sun Red', 'Emperor', 'Pinotage', and 'Zinfandel'), two V. labrusca genotypes ('Videira 889' and 'Goethe'), and two hybrids ('Baco Blanc' and 'Paulistinha'). The explants were placed in test tubes $(25 \times 150 \mathrm{~mm})$ containing WPM culture medium (Lloyd \& McCown, 1980), supplemented with $10 \mathrm{~g} \mathrm{~L}^{-1}$ of sucrose, solidified with $7.0 \mathrm{~g} \mathrm{~L}^{-1}$ of agar, with $\mathrm{pH}$ adjusted to $5.8 \pm 0.1$, and autoclaved at $121^{\circ} \mathrm{C}$, with a pressure of $1.3 \mathrm{~atm}$, for $20 \mathrm{~min}$.

The following temperatures for short-term storage of the genotypes were evaluated: 10,20 , and $25^{\circ} \mathrm{C}$, in a growing room with a light intensity of $38 \mu \mathrm{mol} \mathrm{m} \mathrm{m}^{-2} \mathrm{~s}^{-1}$ and a 12-hour photoperiod. The in vitro storage period was six months, and the following variables were measured monthly: survival percentage, shoot height $(\mathrm{cm})$, number of buds, and growth rate $(\%)$. The experimental design was a completely randomized block, in a $3 \times 10$ factorial arrangement (three temperatures $x$ ten genotypes), with six replicates, each unit consisting of a test tube with one shoot.

After the in vitro storage period, nodal segments of four $V$. vinifera genotypes ('Brasil', 'Sun Red', 'Pinotage', and 'Zinfandel'), two V. labrusca genotypes ('Videira 889' and 'Goethe'), and two hybrids ('Baco Blanc' and 'Paulistinha') were used as the source of explants to be assessed for large-scale in vitro propagation. The segments had about $1.0 \mathrm{~cm}$ long, with one axillary bud, and were taken from the best maintenance temperature group.

For the in vitro propagation phase, a $1 / 2 \mathrm{MS}$ culture medium supplemented with sucrose $\left(20 \mathrm{~g} \mathrm{~L}^{-1}\right)$, benzylaminopurine (BAP, $4.4 \mu \mathrm{mol} \quad \mathrm{L}^{-1}$ ), and naphthaleneacetic acid (NAA, $0.05 \mu \mathrm{mol} \mathrm{L}^{-1}$ ), solidified with agar $\left(7.0 \mathrm{~g} \mathrm{~L}^{-1}\right)$, was used. The explants were subjected to five successive subcultures in a 
growing room, with fluorescent light and a photon flux of approximately $38 \mu \mathrm{mol} \mathrm{s} \mathrm{m}^{-1}$, at $25 \pm 2^{\circ} \mathrm{C}$, under a 16-hour photoperiod. In each 35 -day subculture, the proliferation rate and the number and height of the shoots were evaluated. The experimental design was a completely randomized block in a 8x5 factorial arrangement (eight genotypes $\mathrm{x}$ five subcultures), with 15 replicates. Each replicate consisted of a test tube with one shoot.

After the large-scale propagation, three genotypes ('Goethe', 'Baco Blanc', and 'Zinfandel') were randomly selected for the rooting phase. Microshoots taken from the proliferation phase were placed in 250-mL flasks containing $40 \mathrm{~mL}$ of MS (Murashige \& Skoog, 1962) culture medium supplemented with different concentrations of indolbutiric acid (IBA,

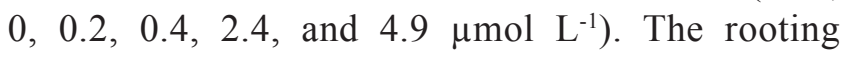
percentage and the number of roots were evaluated after 45 days. The experimental design was a completely randomized block in a $3 \times 5$ factorial arrangement (three genotypes $\mathrm{x}$ five concentrations of IBA), with four replicates.

Once rooted, the plants were removed from the growth flasks and the roots were washed in running water to remove excess growth medium. Subsequently, the plantlets were placed in $250-\mathrm{mL}$ plastic glasses filled with Plantmax substrate. Finally, the plants were transferred to a greenhouse with Sombrite protective screens (at least 50\% light interception), where they remained for up to 30 days, when the survival percentages were determined. A sprinkler irrigation system, with sprinklers located approximately $1.5 \mathrm{~m}$ from the plant material, was used to hydrate the plantlets. Irrigation was triggered by a digital timer at 6-hour intervals for a total of $15 \mathrm{~min}$. No phytosanitary or fertilization treatment was performed on the plantlets during the incubation period in the greenhouse nursery.

Data were subjected to analysis of variance, followed by the Tukey test, at 5\% probability. The data obtained by count (number of roots and number of shoots and buds) were transformed according to $(\mathrm{x}+0.5)^{0.5}$, whereas the data obtained by percentage were transformed by the $\operatorname{arcsine}(\mathrm{x} / 100)^{0.5}$.

\section{Results and Discussion}

There was significant interaction between temperature and genotypes regarding height variables $(\mathrm{cm})$, percentage growth, number of buds, and explant survival during the six-month in vitro conservation period. At $10^{\circ} \mathrm{C}$, all the evaluated genotypes showed weak development, which later resulted in plant death. Genotypes maintained at $25^{\circ} \mathrm{C}$ had an average height of $12.4 \mathrm{~cm}$ and a growth percentage of $1,167.5 \%$, which differed significantly from the explants maintained at $20^{\circ} \mathrm{C}$, with an average height of $11.1 \mathrm{~cm}$ and a growth rate of $973.2 \%$ (Table 1). These results indicate that reducing the temperatures from 25 to $20^{\circ} \mathrm{C}$ was effective for short-term in vitro storage of the grape genotypes. Temperature reduction is one of the first factors to be tested for in vitro conservation of a species. However, for each species, there is a limit that allows growth to be

Table 1. Shoot length and growth rate, number of buds, and survival of grapevine genotypes during six months of in vitro storage at 20 and $25^{\circ} \mathrm{C}^{(1)}$.

\begin{tabular}{|c|c|c|c|c|c|c|c|c|c|}
\hline \multirow[t]{2}{*}{ Species } & \multirow[t]{2}{*}{ Genotype } & \multicolumn{2}{|c|}{ Shoot length $(\mathrm{cm})$} & \multicolumn{2}{|c|}{ Shoot growth rate $(\%)$} & \multicolumn{2}{|c|}{ Number of buds } & \multicolumn{2}{|c|}{ Survival (\%) } \\
\hline & & $20^{\circ} \mathrm{C}$ & $25^{\circ} \mathrm{C}$ & $20^{\circ} \mathrm{C}$ & $25^{\circ} \mathrm{C}$ & $20^{\circ} \mathrm{C}$ & $25^{\circ} \mathrm{C}$ & $20^{\circ} \mathrm{C}$ & $25^{\circ} \mathrm{C}$ \\
\hline Vitis labrusca & 'Videira 889' & $12.4 \mathrm{bA}$ & $16.4 \mathrm{bB}$ & $1,013.1 \mathrm{bA}$ & $1,540.0 \mathrm{bB}$ & $12.6 \mathrm{cA}$ & $20.8 \mathrm{eB}$ & $100.0 \mathrm{aA}$ & $60.0 \mathrm{aA}$ \\
\hline Hybrid & 'Baco Blanc' & $15.1 \mathrm{cA}$ & $16.0 \mathrm{bA}$ & $1,410.0 \mathrm{cA}$ & $1,500.0 \mathrm{bA}$ & $12.4 \mathrm{cA}$ & $18.0 \mathrm{~dB}$ & $80.0 \mathrm{aA}$ & $20.0 \mathrm{bB}$ \\
\hline V. labrusca & 'Goethe' & $15.6 \mathrm{cA}$ & $15.9 \mathrm{bA}$ & $1.460 .0 \mathrm{cA}$ & $1,490.0 \mathrm{bA}$ & $12.4 \mathrm{cA}$ & $22.2 \mathrm{eB}$ & $60.0 \mathrm{aA}$ & $60.0 \mathrm{aA}$ \\
\hline Hybrid & 'Paulistinha' & $-(2)$ & $14.0 \mathrm{~b}$ & - & $1,300.0 b$ & - & $11.2 \mathrm{c}$ & - & $40.0 \mathrm{~b}$ \\
\hline$V$. vinifera & 'Brasil' & $10.1 \mathrm{bA}$ & $16.6 \mathrm{bB}$ & $840.8 \mathrm{bA}$ & $1,560.0 \mathrm{bB}$ & $8.8 \mathrm{bA}$ & $12.0 \mathrm{cA}$ & $100.0 \mathrm{aA}$ & $100.0 \mathrm{aA}$ \\
\hline$V$. vinifera & 'Flora' & $5.3 \mathrm{aA}$ & $4.0 \mathrm{aA}$ & $370.0 \mathrm{aA}$ & $300.0 \mathrm{aA}$ & $5.8 \mathrm{aA}$ & $4.8 \mathrm{aA}$ & $80.0 \mathrm{aA}$ & $80.0 \mathrm{aA}$ \\
\hline$V$. vinifera & 'Sun Red' & $4.5 \mathrm{aA}$ & $4.6 \mathrm{aA}$ & $331.5 \mathrm{aA}$ & $392.5 \mathrm{aA}$ & $5.2 \mathrm{aA}$ & $7.2 \mathrm{bA}$ & $100.0 \mathrm{aA}$ & $60.0 \mathrm{aA}$ \\
\hline$V$. vinifera & 'Emperor' & $13.0 \mathrm{c}$ & - & $1,204.0 \mathrm{c}$ & - & $8.4 \mathrm{~b}$ & - & $40.0 \mathrm{~b}$ & - \\
\hline$V$. vinifera & 'Pinotage' & $13.7 \mathrm{cA}$ & $15.2 \mathrm{bA}$ & $1,169.5 \mathrm{cA}$ & $1,281.5 \mathrm{bA}$ & $14.2 \mathrm{cA}$ & $18.0 \mathrm{~dB}$ & $100.0 \mathrm{aA}$ & $80.0 \mathrm{aA}$ \\
\hline$\underline{V}$ vinifera & 'Zinfandel' & $10.6 \mathrm{bA}$ & $13.4 \mathrm{bA}$ & $960.0 \mathrm{bA}$ & $1,143.4 \mathrm{bA}$ & $11.0 \mathrm{cA}$ & $18.0 \mathrm{~dB}$ & $80.0 \mathrm{aA}$ & $60.0 \mathrm{aA}$ \\
\hline Mean & & $11.1 \mathrm{~A}$ & $12.4 \mathrm{~B}$ & $973.2 \mathrm{~A}$ & $1,167.5 \mathrm{~B}$ & $10.1 \mathrm{~A}$ & $14.7 \mathrm{~B}$ & $82.2 \mathrm{~A}$ & $62.2 \mathrm{~B}$ \\
\hline
\end{tabular}


slowed down without causing physiological damage to the plant. Reduced growth under low temperatures has been used successfully in the in vitro storage of various species, such as Asparagus officinalis L. (Bekheet, 2000), Vanilla planifolia Andrews (Divakaran et al., 2006), and Piper aduncum L. and P. hispidinervum C. DC (Silva \& Scherwinski-Pereira, 2011).

Overall, the number of buds formed by the explant was greater in the genotypes maintained at $25^{\circ} \mathrm{C}$, with an average of 14.7 buds per explant (Table 1). At $20^{\circ} \mathrm{C}$, this number was significantly lower, with an average of 10.1 buds per explant. A similar effect was reported by Fortes \& Scherwinski-Pereira (2001), who found a high number of buds in explants maintained at $25^{\circ} \mathrm{C}$ during the in vitro conservation of potato. After six months of in vitro storage, the percentage of live explants was higher in the sample conserved at a temperature of $20^{\circ} \mathrm{C}$, with an average of $82.2 \%$, differing significantly from those maintained at $25^{\circ} \mathrm{C}$, with an average of $62.2 \%$ (Table 1).

For the 'Brasil' genotype, no explant death occurred at either temperature. The 'Baco Blanc' genotype had a low explant survival rate at $25^{\circ} \mathrm{C}$, with an average of only $20 \%$, which differed significantly from the explants maintained at $20^{\circ} \mathrm{C}$, with an average of $80 \%$ survival. In the other genotypes analyzed, temperature did not affect survival. Divakaran et al. (2006), in studies of in vitro conservation of $V$. planifolia, achieved a survival rate of $80 \%$ after 12 months of conservation.

According to Scherwinski-Pereira \& Costa (2010), the temperature for tropical climate species should be reduced to slow down the growth of explants cultivated in vitro. In the present study, a reduction of $5^{\circ} \mathrm{C}$ in temperature slowed growth, allowing the storage and the survival of the explants. A lower temperature $\left(10^{\circ} \mathrm{C}\right)$ caused explant death, whereas a higher temperature $\left(25^{\circ} \mathrm{C}\right)$ resulted in an accentuated drop in the survival rate, making it unviable to maintain the explants for a long period, due to the excessive shoot growth and death.

There was a significant interaction between genotypesandsubculturesregardingthenumberofshoots and buds formed when large-scale micropropagation was done (Table 2). The highest number of shoots was verified in the subcultures 4 and 5, with averages of 4.9 and 4.8 shoots per explant, respectively. The induction of bud growth is a characteristic of BAP. Similar results were observed in cultivars of Vitis, with a culture medium supplemented with $4.0 \mu \mathrm{mol} \mathrm{L} \mathrm{L}^{-1}$ of BAP (Skiada et al., 2009). Alizadeh \& Singh (2009) also reported multiple shoots in the in vitro culture of grapevines, especially with BAP concentrations of $2.0 \mathrm{mg} \mathrm{L}^{-1}$.

No significant differences were observed between the genotypes 'Baco Blanc' and 'Pinotage' in terms of the number of shoots in the various subcultures analyzed. However, the other genotypes showed fewer shoots in the subcultures 1 and 2, with averages of 2.3 and 2.6 shoots per explant, respectively. There was also a significant increase from the third subculture on. A similar effect was observed by Machado et al. (2006) in the in vitro propagation of grapevines. These authors found a significant increase in the number of shoots among subcultures treated with phytohormones, indicating the need to test a minimum

Table 2. Number of shoots and buds per explant of grapevine genotypes after six months of in vitro storage, followed by five successive subcultures (Subc.) $)^{(1)}$.

\begin{tabular}{|c|c|c|c|c|c|c|c|c|c|c|c|}
\hline \multirow[t]{2}{*}{ Species } & \multirow[t]{2}{*}{ Genotype } & \multicolumn{5}{|c|}{ Number of shoots } & \multicolumn{5}{|c|}{ Number of buds } \\
\hline & & Subc. 1 & Subc. 2 & Subc. 3 & Subc. 4 & Subc. 5 & Subc. 1 & Subc. 2 & Subc. 3 & Subc. 4 & Subc. 5 \\
\hline Vitis labrusca & 'Videira 889' & $2.9 \mathrm{aB}$ & $2.0 \mathrm{aB}$ & $4.6 \mathrm{aA}$ & $5.4 \mathrm{bA}$ & $5.4 \mathrm{bA}$ & $7.1 \mathrm{aB}$ & $7.3 \mathrm{aB}$ & $10.7 \mathrm{aA}$ & $11.7 \mathrm{bA}$ & $11.0 \mathrm{aA}$ \\
\hline Hybrid & 'Baco Blanc' & $1.8 \mathrm{aA}$ & $1.9 \mathrm{aA}$ & $2.5 \mathrm{bA}$ & $2.9 \mathrm{cA}$ & $3.2 \mathrm{cA}$ & $6.9 \mathrm{aA}$ & $6.1 \mathrm{aA}$ & $6.4 \mathrm{bA}$ & $8.3 \mathrm{cA}$ & $7.8 \mathrm{bA}$ \\
\hline V. labrusca & 'Goethe' & $2.9 \mathrm{aB}$ & $2.1 \mathrm{aB}$ & $4.1 \mathrm{aA}$ & $5.1 \mathrm{bA}$ & $4.8 \mathrm{bA}$ & $9.1 \mathrm{aB}$ & $8.1 \mathrm{aB}$ & $10.0 \mathrm{aB}$ & $13.2 \mathrm{bA}$ & $13.8 \mathrm{aA}$ \\
\hline Hybrid & 'Paulistinha' & $2.9 \mathrm{aB}$ & $3.1 \mathrm{aB}$ & $5.3 \mathrm{aA}$ & $5.7 \mathrm{bA}$ & $5.4 \mathrm{bA}$ & $6.1 \mathrm{aC}$ & $7.4 \mathrm{aC}$ & $10.4 \mathrm{aB}$ & $14.1 \mathrm{bA}$ & $14.0 \mathrm{aA}$ \\
\hline$V$. vinifera & 'Brasil' & $2.0 \mathrm{aB}$ & $2.0 \mathrm{aB}$ & $2.3 \mathrm{bB}$ & $3.7 \mathrm{cA}$ & $3.6 \mathrm{cA}$ & $5.1 \mathrm{aB}$ & $5.3 \mathrm{aB}$ & $4.6 \mathrm{bB}$ & $9.4 \mathrm{cA}$ & $9.2 \mathrm{bA}$ \\
\hline V. vinifera & 'Sun Red' & $2.8 \mathrm{aC}$ & $2.8 \mathrm{aC}$ & $5.5 \mathrm{aB}$ & $7.5 \mathrm{aA}$ & $7.8 \mathrm{aA}$ & $8.7 \mathrm{aB}$ & $8.8 \mathrm{aB}$ & $10.5 \mathrm{aB}$ & $16.5 \mathrm{aA}$ & $16.0 \mathrm{aA}$ \\
\hline V. vinifera & 'Pinotage' & $2.4 \mathrm{aA}$ & $1.9 \mathrm{aA}$ & $3.3 \mathrm{bA}$ & $2.9 \mathrm{cA}$ & $3.0 \mathrm{cA}$ & $6.3 \mathrm{aA}$ & $6.8 \mathrm{aA}$ & $7.1 \mathrm{bA}$ & $6.6 \mathrm{cA}$ & $6.6 \mathrm{bA}$ \\
\hline V. vinifera & 'Zinfandel' & $3.1 \mathrm{aB}$ & $2.8 \mathrm{aB}$ & $4.1 \mathrm{aB}$ & $6.2 \mathrm{bA}$ & $6.0 \mathrm{bA}$ & $7.8 \mathrm{aB}$ & $10.1 \mathrm{aB}$ & $7.9 \mathrm{bB}$ & $15.6 \mathrm{aA}$ & $13.7 \mathrm{aA}$ \\
\hline Mean & & $2.3 \mathrm{C}$ & $2.6 \mathrm{C}$ & $4.0 \mathrm{~B}$ & $4.9 \mathrm{~A}$ & $4.8 \mathrm{~A}$ & $7.1 \mathrm{C}$ & $7.5 \mathrm{C}$ & $8.4 \mathrm{~B}$ & $11.7 \mathrm{~A}$ & $11.4 \mathrm{~A}$ \\
\hline
\end{tabular}

${ }^{(1)}$ Means followed by equal letters, lower case in the columns and upper case in the lines, within each variable, do not differ by Tukey's test, at $5 \%$ probability. 
of three subcultures to obtain better results in the mass propagation of the species.

The hybrids showed different responses from the third subculture on. The 'Paulistinha' genotype had a higher shoot production than the 'Baco Blanc' one, with averages of 5.3 and 2.5 shoots per explant, respectively. Bernd et al. (2007), while evaluating grapevine hybrids, obtained an average of 4.9 shoots per explant in a culture medium supplemented with $3.0 \mu \mathrm{mol} \mathrm{L}^{-1}$ of BAP. Torregrosa \& Bouquet (1995), in a study with different grapevine hybrids, observed that a concentration of $4.4 \mu \mathrm{mol} \mathrm{L}^{-1}$ of BAP resulted in better rates of multi-budding. Skiada et al. (2009), when assessing Vitis spp. cultivars, defined BAP concentrations between 4.0 and $16 \mu \mathrm{mol} \mathrm{L}^{-1}$ as optimum for in vitro propagation of the species, and between 0.5 and $1.0 \mu \mathrm{mol} \mathrm{L^{-1 }}$ as optimum for the production of shoots with greater above-the-ground height. These authors concluded that higher concentrations of BAP retard explant growth and favor better shoot production.

At the concentration of BAP used in the present study, symptoms of vitrification were observed in some shoots. This is a common problem encountered in grapevine in vitro cultivation, especially with high concentrations of BAP. According to Heloir et al. (1997), BAP concentrations must be adapted to each cultivar, optimizing the process to obtain good quality shoots with minimum vitrification, even if it means lower propagation rates, since subsequent phases of rooting and acclimatization depend on the good physiological condition of the shoots.

A larger number of buds, from the third subculture on, was observed in the genotypes 'Videira 889' and 'Paulistinha', when compared to the other ones, with an average of 10.4 and 10.7 buds per explant, respectively. The 'Brasil', 'Sun Red', 'Zinfandel', and 'Goethe' genotypes showed a significant increase in number of buds only in the fourth subculture. Machado et al. (2006) observed an increase in the number of buds in subcultures on 'VR043-43' grapevine grafting stock. Dzazio et al. (2002) obtained numbers of buds higher than that of the control group with a concentration of $1.0 \mu \mathrm{mol} \mathrm{L}{ }^{-1}$ of BAP.

The concentration of IBA had a significant effect on rooting of the genotypes (Table 3 ). The highest number of roots formed was found at a concentration of $0.4 \mu \mathrm{mol} \mathrm{L}^{-1}$ of IBA, with an average of 3.3 roots per explant, followed by the treatments at 2.4 and $4.9 \mu \mathrm{mol}$ $\mathrm{L}^{-1}$ IBA concentrations, yielding averages of 3.0 and 2.6 , respectively. These results were similar to those reported by Biasi et al. (1998), in which the explants emitted an average of 2.8 roots on 'Jales' grafting stock. For some cultivars, the presence of auxin in the culture medium is essential for good rooting. Bernd et al. (2007), using a culture medium supplemented with NAA at a concentration of $8.05 \times 10^{-3} \mu \mathrm{mol} \mathrm{L} \mathrm{L}^{-1}$, observed rooting of all the plants from the propagation treatments with BAP, at concentrations of 3.5 and $10 \mu \mathrm{mol} \mathrm{L}^{-1}$.

Rhizogenesis in grapevines seems to be strongly genotype-dependent (Lewandowski, 1991). In the present study, the 'Goethe' ( $V$. labrusca) genotype emitted five roots per explant at a concentration of $2.4 \mu \mathrm{mol} \mathrm{L}{ }^{-1}$, which differed significantly from the other treatments. At a concentration of $4.9 \mu \mathrm{mol} \mathrm{L} \mathrm{L}^{-1}$, there was no significant difference when compared to the control group (1.8 and 0.7 roots per explants, respectively). However, for the 'Baco Blanc' (hybrid) genotype, the best outcomes were obtained at the concentrations of 0.4 and $2.4 \mu \mathrm{mol} \mathrm{L} \mathrm{L}^{-1}$, with 3.3 and 2.8 roots per explant. No significant differences were observed between the different concentrations of IBA evaluated with the 'Zinfandel' ( $V$. vinifera) genotype (Table 3).

Following the rooting period, rooted plants of the 'Goethe', 'Paulistinha', and 'Baco Blanc' genotypes were acclimatized. A 95.8\% survival rate was achieved after 30 days planted in Plantmax substrate. These data corroborate those of Dzazio et al. (2002), who, while working with '420-A' rootstock, obtained a 95.8\% survival rate in Vermiculite and $87.50 \%$ survival rate in Plantmax.

Tabela 3. Number of roots per shoot of grapevine genotypes with indolbutiric acid (IBA) in the culture medium ${ }^{(1)}$.

\begin{tabular}{lcccc}
\hline IBA $\left(\mu \mathrm{mol} \mathrm{L}^{-1}\right)$ & 'Goethe' & 'Baco Blanc' & 'Zinfandel' & Mean \\
\hline 0.0 & $0.7 \mathrm{cA}$ & $0.5 \mathrm{bA}$ & $0.1 \mathrm{bA}$ & $0.4 \mathrm{c}$ \\
0.2 & $2.9 \mathrm{bA}$ & $1.7 \mathrm{abA}$ & $2.1 \mathrm{aA}$ & $2.2 \mathrm{~b}$ \\
0.4 & $3.4 \mathrm{abA}$ & $3.1 \mathrm{aA}$ & $2.1 \mathrm{aA}$ & $3.3 \mathrm{a}$ \\
2.4 & $5.0 \mathrm{aA}$ & $2.0 \mathrm{abB}$ & $2.1 \mathrm{aB}$ & $3.0 \mathrm{ab}$ \\
4.9 & $1.8 \mathrm{bcA}$ & $2.8 \mathrm{aA}$ & $3.1 \mathrm{aA}$ & $2.6 \mathrm{ab}$ \\
\hline
\end{tabular}

${ }^{(1)}$ Means followed by equal letters, lower case in the columns and upper case in the lines, do not differ by Tukey's test, at $5 \%$ probability. 


\section{Conclusions}

1. Grapevine genotypes can be stored in vitro for six months in WPM culture medium, at $20^{\circ} \mathrm{C}$.

2. Grapevine genotypes maintained in vitro for six months, at $20^{\circ} \mathrm{C}$, can be micropropagated in large scale in a culture medium of $1 / 2 \mathrm{MS}+4.4 \mu \mathrm{mol} \mathrm{L}-1$ of benzylaminopurine and $0.05 \mu \mathrm{mol} \mathrm{L}^{-1}$ of naphthaleneacetic acid.

3. Grapevine rooting can be accomplished in a MS culture medium with $0.4 \mu \mathrm{mol} \mathrm{L}{ }^{-1}$ of indolbutiric acid, planted in Plantmax substrate and acclimatized in a nebulization chamber, with survival rates above $95 \%$.

\section{Acknowledgements}

To Conselho Nacional de Desenvolvimento Científico e Tecnológico, for financial support.

\section{References}

ALIZADEH, M.; SINGH, S.K. Molecular assessment of clonal fidelity in micropropagated grape (Vitis spp.) rootstock genotypes using RAPD and ISSR markers. Iranian Journal of Biotechnology, v.7, p.37-44, 2009.

BEKHEET, S.A. In vitro preservation of Asparagus officinalis. Biologia Plantarum, v.43, p.179-183, 2000.

BERND, R.B.; TRIVILIN, A.P.; CAMARGO, U.A.; CZERMAINSKI, A.B.C. Micropropagação de porta-enxertos híbridos de Vitis labrusca $\mathrm{x}$ Vitis rotundifolia com resistência à pérola-da-terra (Eurhizococcus brasiliensis Hempel, Hemiptera: Margarodidae). Revista Brasileira de Fruticultura, v.29, p.350-354, 2007.

BIASI, L.A.; PASSOS, I.R. da S.; POMMER, C.V. Micropropagação do porta-enxerto de videira Jales. Pesquisa Agropecuária Brasileira, v.33, p.1587-1594, 1998.

DIVAKARAN, M.; BABU, K.N.; PETER, K.V. Conservation of Vanilla species, in vitro. Scientia Horticulturae, v.110, p.175-180, 2006.

DZAZIO, P.M.; BIASI, L.A.; ZANETTE, F. Micropropagação do porta-enxerto de videira '420-A'. Revista Brasileira de Fruticultura, v.24, p.759-764, 2002.

ENGELMANN, F. Use of biotechnologies for conserving plant biodiversity. Acta Horticulturae, v.812, p.63-82, 2009.

FOOD AND AGRICULTURE ORGANIZATION OF THE UNITED NATIONS. Faostat. 2010. Available at: http://faostat.fao. org/site/567/DesktopDefault.aspx?PageID=567\#ancor $>$. Accessed on: 27 Jan 2012.

FORTES, G.R. de L.; SCHERWINSKI-PEREIRA, J.E. Preservação in vitro da batata com ácido acetilsalicílico e duas fontes de carboidrato. Pesquisa Agropecuária Brasileira, v.36, p.1261-1264, 2001.

HELOIR, M.C.; FOURNIOUX, J.C.; OZIOL, L.; BESSIS, $\mathrm{R}$. An improved procedure for the propagation in vitro of grapevine (Vitis vinifera cv. Pinot noir) using axillary-bud microcuttings. Plant Cell, Tissue and Organ Culture, v.49, p.223-225, 1997.

LEÃO, P.C. de S.; MOTOIKE, S.Y. Genetic diversity in table grapes based on RAPD and microsatellite markers. Pesquisa Agropecuária Brasileira, v.46, p.1035-1044, 2011.

LEWANDOWSKI, V.T. Rooting and acclimatization of micropropagated Vitis labrusca 'Delaware'. HortScience, v.26, p.586-589, 1991.

LLOYD, G.; MCCOWN, B. Commercially-feasible micropropagation of mountain laurel, Kalmia latifolia, by use of shoot-tip culture. Combined Proceedings of International Plant Propagators' Society, v.30, p.421-427, 1980.

MACHADO, M.P.; BIASI, L.A.; RITTER, M.; RIBAS, L.L.F.; KOEHLER, H.S. Multiplicação in vitro do porta-enxerto de videira 'VR043-43' (Vitis vinifera $\mathrm{x}$ Vitis rotundifolia). Ciência e Agrotecnologia, v.30, p.648-655, 2006.

MURASHIGE, T.; SKOOG, F. A revised medium for rapid growth and bio assays with tobacco tissue cultures. Physiology Plantarum, v.15, p.473-479, 1962.

RAY, A.; BHATTACHARYA, S. Storage and conversion of Eclipta alba synseeds and RAPD analysis of converted plantlets. Biologia Plantarum, v.54, p.547-550, 2010.

SANTANA, J.C.; HIDALGO, E.; LUCAS, A.I. de; RECIO, P.; ORTIZ, J.M.; MARTÍN, J.P.; YUSTE, J.; ARRANZ, C.; RUBIO, J.A. Identification and relationships of accessions grown in the grapevine (Vitis vinifera L.) Germplasm Bank of Castilla y Léon (Spain) and the varieties authorized in the VQPRD areas of the region by SSR-marker analysis. Genetic Resources and Crop Evolution, v.55, p.573-583, 2008.

SCHERWINSKI-PEREIRA, J.E.; COSTA, F.H.S. Conservação in vitro de recursos genéticos de plantas: estratégias, princípios e aplicações. In: BARRUETO CID, L.P. (Org.). Cultivo in vitro de plantas. Brasília: Embrapa Informação Tecnológica, 2010. p.177-234.

SCHUCK, M.R.; BIASI, L.A.; MARIANO, A.M.; LIPSKI, B.; RIAZ, S.; WALKER, M.A. Obtaining interspecific hybrids, and molecular analysis by microsatellite markers in grapevine. Pesquisa Agropecuária Brasileira, v.46, p.1480-1488, 2011.

SILVA, T.L.; SCHERWINSKI-PEREIRA, J.E. In vitro conservation of Piper aduncum and Piper hispidinervum under slow-growth conditions. Pesquisa Agropecuária Brasileira, v.46, p.384-389, 2011.

SKIADA, F.G.; GRIGORIADOU, K.; MALIOGKA, V.I.; KATIS, N.I.; ELEFTHERIOU, E.P. Elimination of grapevine leafroll-associated virus 1 and grapevine rupestris stem pitting-associated virus from grapevine cv. Agiorgitiko, and a micropropagation protocol for mass production of virus-free plantlets. Journal of Plant Pathology, v.91, p.177-184, 2009. 
TORREGROSA, L.; BOUQUET, A. In vitro propagation of Vitis $\mathrm{x}$ Muscadinia hybrids by microcuttings or axillary budding. Vitis, v.34, p.237-238, 1995.

VASANTH, K.; VIVIER, M.A. Improved cryopreservation procedure for long storage of synchronized culture of grapevine. Biologia Plantarum, v.55, p.365-369, 2011.
WANG, Q.; MAWASSI, M.; SAHAR, N.; LI, P.; VIOLETA, C.T.; GAFNY, R.; SELA, I.; TANNE, E.; PERL, A. Cryopreservation of grapevine (Vitis spp.) embryogenic cell suspensions by encapsulation-vitrification. Plant Cell, Tissue and Organ Culture, v.77, p.267-275, 2004.

Received on December 20, 2010 and accepted on January 29, 2012 